\title{
Management of Bengal gram seed production by Karnataka state seeds corporation (KSSC) Ltd., Gadag
}

\section{PAVITRA O. PATIL AND N.M. KERUR}

Received : 17.08.2017; Revised : 07.09.2017; Accepted : 21.09.2017

\begin{abstract}
The present study was conducted in Gadag district for the study, 50 bengalgram seed production farmers were selected randomly in the study area. All five taluks of Gadag district were considered for study and the results obtained through simple averages and percentages. The results revealed that, estimated per hectare cost of production of bengalgram seed was Rs 34,940.97. The per hectare average yield of bengalgram seed was 14.37 quintal. The per quintal procurement price was Rs. 6,066.00. The gross returns of bengalgram seeds were Rs. 87,168.42 per hectare. The net returns of bengalgram seeds was Rs. $50,767.01$ and returns per rupee of investment was 1.45.
\end{abstract}

KEY WORDS : Production, Cost, Returns, KSSC, Bengalgram

How to cite this paper : Patil, Pavitra O. and Kerur, N.M. (2017). Management of Bengal gram seed production by Karnataka state seeds corporation (KSSC) Ltd., Gadag. Internat. J. Com. \& Bus. Manage, 10(2) : 213-217, DOI: 10.15740/HAS/IJCBM/10.2/213-217.

\section{MEMBERS OF THE RESEARCH FORUM}

Correspondence to:

PAVITRA O. PATIL, Department of Agribusiness Management, College of Agriculture, University of Agricultural Sciences, DHARWAD (KARNATAKA) INDIA

Authors' affiliations:

N.M. KERUR, Department of Agribusiness Management, College of Agriculture, University of Agricultural Sciences, DHARWAD (KARNATAKA) INDIA

Email: kerur_nm@yahoo.com 